\title{
ILCEA
}

Revue de l'Institut des langues et cultures

d'Europe, Amérique, Afrique, Asie et Australie

19 | 2014

Acceptabilité et transgression en langues et cultures de spécialité

\section{Towards a Cognitive Approach to Notions of Acceptability and Transgression in Spelling and Punctuation in Workplace Communication}

Vers une approche cognitive de l'acceptabilité de transgressions langagières:

l'orthographe et la ponctuation dans la communication professionnelle

Inesa Sakalian-Merle des Isles

\section{OpenEdition}

Journals

Electronic version

URL: http://journals.openedition.org/ilcea/2465

DOI: $10.4000 /$ ilcea.2465

ISSN: 2101-0609

Publisher

UGA Éditions/Université Grenoble Alpes

Printed version

ISBN: 978-2-84310-280-6

ISSN: $1639-6073$

Electronic reference

Inesa Sakalian-Merle des Isles, « Towards a Cognitive Approach to Notions of Acceptability and Transgression in Spelling and Punctuation in Workplace Communication », ILCEA [Online], 19 | 2014 Online since 27 June 2014, connection on 01 May 2019. URL : http://journals.openedition.org/ ilcea/2465 ; DOI : 10.4000/ilcea.2465

This text was automatically generated on 1 May 2019.

(C) ILCEA 


\title{
Towards a Cognitive Approach to Notions of Acceptability and Transgression in Spelling and Punctuation in Workplace Communication
}

\author{
Vers une approche cognitive de l'acceptabilité de transgressions langagières : \\ l'orthographe et la ponctuation dans la communication professionnelle
}

Inesa Sakalian-Merle des Isles

1 With the growing dominance of English as the global language, the needs of workplace communication have evolved and the knowledge of English has become an indispensable part of professional competence, irrespective of the domain of specialisation. As Nickerson (2013, p. 450) notes "the ability to communicate effectively in English provides support for business activities in the same way that being able to use Microsoft PowerPoint effectively also does or the ability to understand financial transactions". Further, with the advent of information technologies, communication has reached an outstanding level of efficiency and information is today communicated rapidly, abundantly and globally. Being constantly 'within reach', especially through hand-held technology, implies a great degree of communicative reactivity, which sometimes leaves little room for properly constructed grammatical sentences. The following example, reproduced from Bob Hirschfield (1999), is revealing of how the primacy awarded to efficiency jeopardizes standard language norms and puts into question the relevance of grammatical accuracy in workplace contexts.

One morning, an American chief executive officer repeatedly tried to send an email and each time he got back an error message saying, "The dependent clause preceding the independent clause must be set off by commas, but must not precede the conjunction" (Hirschfeld, 1999). Just about the same time, another top executive at a telecommunications and long-distance company reported a similar 
malfunction expressed in less obscure terms, "This morning, the same damned email kept coming back to me with a pesky notation claiming I needed to use a pronoun's possessive case before a gerund. With the number of e-mails I crank out each day, who has time for proper grammar?" (Ibid.) [My emphasis] These executives were both victims of a new Internet virus. Named the Pluperfect Virus, or 'the Strunkenwhite', after the authors of a classic American style guide by William Strunk and E.B. White, it spread throughout the Internet and refused delivery of email messages containing grammatical or spelling mistakes.

While the term 'Strunkenwhite' was the fruit of the imagination of Bob Hirschfeld, featured in a satire published in The Washington Post in May 1999, the situation depicted is far from being fictional. Rather, it is revealing of the quality of the language used in today's business communication governed by the hegemony of a 'time is money' attitude. As such, the quality of the language used is often sacrificed to the expediency of its communication. What matters is to get the message across in the least possible time.

In contrast, we would like to propose an example from a crime fiction novel, The Riddle of the Third Mile (1983) by Colin Dexter indicative of a more traditional counter attitude to grammar norms and, in particular, to punctuation in the beginning of 1980s in the academic context of Oxford University. The transgression of punctuation norms in a note left at the college lodge raises serious doubts as to the identity of the real author in view of the intolerance of its presumed author, Professor Browne-Smith, towards grammatical solecisms. The message left in the form of a note reads:

Please keep any mail for me here. I shall be away for several days. Sudden irresistible offer-quite out of the blue. Tell my scout to look after my effects, i.e. to keep the rooms well dusted, put the laundry through and cancel all meals until further notice. B.-S. (1983, p. 46)

While the message seems to meet contemporary standard language norms, the college Master doubts that the note was ever written by Professor Browne-Smith, a stickler for proper punctuation, who would have never omitted to put commas after 'sudden', 'through' and even, 'i.e.'.

4 Though fictional, the above examples represent contrasting attitudes to transgressions of language norms, which range from absolute acceptability to zero tolerance. For some, standard languages "have to be maintained and protected through authority and doctrines of correctness" (Milroy, 2007, p. 138), with zero tolerance of transgressions of language norms (Truss, 2003), while, to others, this doctrinal attitude to the maintenance of language norms is "identifiable with the eighteenth-century hope that language could be fixed, a time when grammarians were trying to construct a set of norms in order to establish and then preserve good usage" (Garrett, 2010, p. 9). In this perspective, attempts to preserve standard language have been referred to as "an illusion based on misunderstandings about the nature of language, values and human nature" (Algeo, 1998, p. 178 in Garrett, 2010, p. 9).

5 The contrast of the attitudes to grammar norms in different time scales and contexts is striking. This would suggest that the prevalence of communicative efficiency over grammatical accuracy is largely spurred by modern communication strategies on the one hand, and the needs and expectations of professional contexts, on the other. As Nickerson (2013) observes, drawing on David Graddol's 2006 report for the British Council, "the rise in the importance of global English will lead to a corresponding fall in the relevance of native speaker models both for the teaching of English and for how speakers (of global English) are evaluated" (p. 447). Indeed, the expansion of English as a 
lingua franca in today's globalized world generates debate about the importance of correct standard language, and thereby the acceptability of deviant language forms.

In his pioneering study on the co-evolution of language and the human brain, Symbolic Species, the American anthropologist Terrence Deacon (1997) addresses the language problem in the light of the evolutionary theory of human development. With regard to the purpose of language acquisition and usage, Deacon claims that "common factor in the use of language is an intention to convey something that the other person presumably doesn't know" (1997, p. 58). Hence, from the evolutionary perspective, communication of information is pointed to as the primary purpose of language acquisition. In a similar stance, the capacity to communicate is put forward by The Common European Framework of Reference for Languages: Learning, Teaching, Assessment (2011) as the key criterion in the assessment of the linguistic performance of language learners. The question to be asked here is whether it is still of relevance to uphold the principle of maintaining standard language norms, or are transgressions of language norms acceptable inasmuch as the message is conveyed. Otherwise, are transgressions of norms in ESP teaching acceptable as long as they do not hinder the act of communication? This is the central question of our study, and to address it we aim to demonstrate the impact of transgression of norms on the communicative act and examine some criteria of acceptability.

7 The focus of the study is on the relatively little explored field of spelling and punctuation norms, with particular reference to legal documents. Though spelling and punctuation fall under distinct language categories, here they are brought together in view of the relatively minor attention attributed to both spelling and punctuation norms in workplace communication and therefore in ESP teaching. To gain an insight into the pertinence of standard language norms in ESP teaching practices, the study examines the role of standard norms in the processes underlying language acquisition on the one hand, and communication, on the other. Correspondingly, two main lines of enquiry are pursued, first 'what is the role of norms in the process of language acquisition?' and, second, 'do norms matter in contexts of professional communication?'. To address the first enquiry, the theory of cognition developed by the American philosopher and semiotician Charles S. Peirce is of interest here since it helps to shape our understanding of the role of standard norms in the process of language acquisition.

\section{Language acquisition and standard language norms}

8 Central to Peircean theory of cognition is the notion of laws or rules that are built through the experience of various phenomena of the universe and serve to govern and render significant further individual occurrences of these phenomena. However, an important distinction is drawn between two categories of laws-natural and conventional. The former are established by nature (e.g. the laws of physics and chemistry), and can be acquired through direct observation, while the latter, determined by humans through convention (like the Highway Code, the Morse code or natural languages), require awareness of the convention underlying the corresponding law, for they are not obvious through direct observation. In this view, knowledge being a set of general laws, the act of knowing, i.e. cognition, may be considered as referring to the acquisition of such general laws or rules. Peirce explains that "the cognition of a rule is not necessarily conscious, but is of the nature of a habit, acquired or congenital" ( $\left.\mathrm{CP}^{1} 2.711\right)$. 
9 Likewise, Humberto Maturana, a Chilean biologist and philosopher, who has extensively researched the biology of cognition, accounts for the human cognitive function in terms of inductive reasoning based on our past experiences and used to predict future events:

A living system, due to its circular organization, is an inductive system and functions always in a predictive manner: what happened once will occur again. Its organization, (genetic and otherwise) is conservative and repeats only that which works. For this same reason living systems are historical systems; the relevance of a given conduct or mode of behaviour is always determined in the past. (1980, pp. 267)

10 Language acquisition is, therefore, a cognitive process, where the linguistic knowledge (a set of general conventional rules) is acquired through a habit-formation activity. As Peirce notes: "All general, or definable, Words [...] denote the objects that they do by virtue only of there being a habit that associates their signification with them." (CP 4.544) Interestingly, this account derived from a cognitive approach is in line with the position advocated by the American linguist Paul Hopper in his theory of emergent grammar as accounted for by Hoey (2005) "grammar is the output of what he [Hopper] calls 'routines', collocational groupings, the repeated use of which results in the creation of a grammar for each individual" (Chapter 1, Priming as an explanation of collocation, § 4). According to the theory of emergent grammar developed by Hopper, grammar rules emerge as language is used. Finally, in an extensive study on the nature of human language, the Canadian experimental psychologist and cognitive linguist, Steven Pinker (2013) speaks of "human rule-governed intelligence" (Chapter 3, Rules \& Connections in Human Language, § 17).

11 Such findings derived from cognitive and psycholinguistic insights into the nature of linguistic knowledge enhance our enquiry into the pertinence of standard language norms in ESP teaching and learning practices in at least one important way. This approach brings to light the role of general rules or established norms in cognitive processes underlying language acquisition: norms and rules are fundamental to language acquisition in that they constitute our linguistic knowledge. This highlights another important implication: as we shall see further, rules are equally of central importance to the definition of acceptability, insofar as judgements on the acceptability of a linguistic performance necessarily presuppose a reference to some pre-established norms or general rules. As Debièvre (1978, p. 126) explains, it is these general rules constituting our linguistic knowledge that form our linguistic competence which further serves as a reference for judgements on acceptability.

Having established this theoretical framework, in what follows we pursue our second line of enquiry in addressing the question of whether norms matter in workplace communication. The examples studied are relative to spelling and punctuation norms, relatively ignored in workplace communication, in particular, in e-mail correspondence.

\section{Standard language norms and communication: spelling and punctuation norms}

While 'proper' writing presupposes the awareness of a set of grammar and spelling rules, when English is used as a lingua franca, spelling norms are often neglected, a phenomenon that is not new (woz, gonna, gotta, etc.) but further accentuated today by the use of abridged words for texting (CUAT2 $=$ see you at 2 ) and emailing purposes (FYI, BTW, 
TAFN, etc.). Consequently, does spelling matter for learners of ESP? If the communicative capacity of a message were to be considered as the primary criterion of establishing the extent to which grammar rules can be transgressed, the following text from an anonymous author on the Internet in September 2003 would have to be considered as acceptable:

Aoccdrnig to extnesvie rseeacrh conudcetd at Oxofrd Uinervtisy in Enlgnad, it deosn't raelly mttaer in waht oredr the ltteers in a wrod are, the olny iprmoetnt is taht the frist and lsat ltteer is at the rghit pclae.

The rset can be in a toatl mses and you usulaly can sitll raed it wouthit much porbelm. Tihs is bcuseae we do not raed ervey lteter by it slef but the wrod as a wlohe.

Jsut thnik a momnet abuot all the tmie you and I watesed laernnig how to splel wrods croreclty!

As can be seen, in this short text all the words are printed so that, except for the first and last letters, the rest appear in the wrong order, thus transgressing the most basic of spelling norms. Nevertheless, even in its extremely deviant form, the text enables most readers, with lesser or greater degree of ease and rapidity, to reproduce the text by mentally rearranging the letters of the words in their right order and thus allowing for the message to be understood. From the cognitive perspective presented earlier, the interpretation of the message here is made possible due to the reader's awareness of the spelling norms that habitually govern these words. These norms, which correspond to the set of general rules constituting our language knowledge, serve as a basis for reference, comparison and interpretation. Thus, despite the deviant forms present in the above passage, the reader is able to interpret the message by mentally referring to the standard language norms that govern the regular occurrences of these words (encountered and acquired through previous experience). This points to the importance of standard norms in the process of language acquisition in general, as well as in ESP teaching and learning practices.

14 The above phenomenon is further accounted for by the American philosopher, Goodman (1969), as the determinate reading characteristic of verbal systems in his general theory of symbols, which embraces a wide range of arts and symbol systems, such as music, dance, architecture, dramatic scripts. As the title of the book, Languages of Art, suggests, language is placed in the paradigm of this general system of symbols as a particular kind of system. It serves as grounds for comparison and contrast in the definition of all the other systems of representation. As a result, all the systems fall into two major types, linguistic and non-linguistic.

Regarding the functional distinction between the two symbol systems, Goodman claims that "non-linguistic systems differ from languages, depiction from description, the representational from the verbal, paintings from poems, primarily through lack of differentiation-indeed through density (and consequent total absence of articulation)in the symbol scheme" (1969, p. 226). Goodman thus introduces the terms of differentiation and density on which he founds his primary distinction between linguistic and nonlinguistic systems of symbols. To illustrate these notions, let us consider two examples. First, imagine a picture that comprises various lines: straight lines, arrows, curves, a number of objects set on the background and foreground, arranged variously in the central position or in the corners, all these depicted in different colours and colour shades. This picture acts as a dense symbol in that it involves a great number of marks each charged with meaning and open to a wide range of possible interpretations varying 
from person to person. That is to say, no unique determinate reading of the image is possible. On the other hand, the reading of a piece of text is characterised by utmost precision and every character of the system is differentiated in having a definite articulate meaning. Such a differentiated system allows for "definiteness and repeatability of readings" (ibid., p. 161). The latter system has no intermediary characters as is the case, for example, with the gradation of colours in a dense system where each shade of colour stands as a distinct, unique character of its own. Viewed in terms of the linguistic system, if for some reason a character appears to have a distinct mark caused by some distortions (spelling mistakes or careless handwriting), it will be given a reading that is attributed by the system to the next closest character.

In view of this, even a completely misspelled text can still be read and interpreted. That is, as far as spelling norms are concerned, even in case of absolute acceptability of transgression, the message can still get across, and the communicative act be performed. Therefore, the idea that transgressions are acceptable as long as they do not hinder the act of communication falls apart as far as spelling norms are concerned, as even in cases where the limits are pushed very far this does not result in an obstacle to comprehension. Having established this, the question to be considered next is whether zero tolerance of transgressions is relevant in contexts of professional communication where the acquisition of English serves, above all, specific workplace purposes. To answer this question, the following section will examine some cases of transgression of seemingly minor language norms, namely, punctuation norms, in legal documents.

\section{Punctuation norms}

Being related to the subtleties of linguistic use, is the study of punctuation norms relevant for students studying applied languages for use in professional contexts where communication is essentially transactional and interpersonal? An unusually comprehensive answer to these questions figures in a theory of punctuation as set out in Eats, Shoots \& Leaves (2003) by Truss Lynne, in which she advocates the zero tolerance approach to punctuation mistakes. The title of the book derives from the story of the panda, who walks into a cafe, orders a sandwich, eats it, draws a gun and fires two shots in the air. In response to the confused waiter as to the reasons of its behaviour, the panda hands him over a badly punctuated wildlife manual. When the waiter turns to the entry 'panda,' he finds an explanation. "Panda. Large black-and-white bear-like mammal, native to China. Eats, shoots and leaves." In this case, the comma improperly added after the word 'eats', certainly alters the meaning of the statement. Thus, instead of being considered as plural nouns and interpreted as parts of a plant (its shoots and leaves), due to the improperly placed comma, the words 'shoots' and 'leaves' are interpreted as verbs (conjugated in the third person singular). Through this, and other amusing and embarrassing stories, Truss demonstrates that punctuation really does matter, and even if, as she puts it (in the presentation of her book), "it is only occasionally a matter of life and death", she provides examples of serious misunderstandings resulting from 'mere' punctuation errors. Such risks are particularly high with reference to legal documents.

Two revealing examples of the crucial impact of punctuation in such professional contexts and with regard to legal documents, was covered in press in 2002 (see article "Greene family fights for access to papers" by Emma Hartley and Catherine Milner published in The Telegraph on 17 February 2002 and "A Literary Battle That May Hang by A 
Comma" by Sarah Lyall, published in The New York Times on 16 March 2002), and equally cited by Truss Lynne in her book on the crucial role of punctuation (Truss, 2003, p. 101). The first concerns Graham Greene who, in 1991, signed a legally binding document that clearly authorised Norman Sherry to be his official biographer. But before he signed, he inserted a single comma that created a certain degree of ambiguity as to the document's meaning. The document, before correction, stated: "I, Graham Greene, grant permission to Norman Sherry, my authorized biographer, excluding any other to quote from my copyright material published or unpublished.[...]." Greene added a comma after "excluding any other" and died the next day without explaining what he intended by it, resulting in legal confusion: "Are all other researchers excluded from quoting the material, or only other biographers?" As Truss explains, for the librarian at Georgetown, the document meant that nobody other than Norman Sherry could consult the material. Meanwhile others, including Green's son, argued that the comma was carefully inserted by Greene specifically to indicate that Sherry was the sole authorised biographer (Truss, 2003, p. 102).

19 Another example of the important role of punctuation in legal writing derives from a case in which the Kentucky Court of Appeals was called on to interpret a semicolon in a passage from a will to decide whether an estate was to be divided into nine equal parts or into eight parts with one part shared by two parties. The passage of contention read as follows:

I bequeath and devise my entire estate, both personal and real, which may remain after the satisfaction of the above special bequest and the payment of my debts, funeral expenses, and the costs and expenses of the administration of my estate, in equal shares, absolutely and in fee, to my cousin, the said Walter Cassidy; Robert Jamison and William Stivers, tenants of my farm; George E. Smith, who rents my property on Bland Avenue, Shelbyville, Kentucky; and the Kentucky Society for Crippled Children, of Louisville, Kentucky; Baptist Ministers Aid Society, of Owensboro, Kentucky; Baptist Orphan's Home of Louisville, Kentucky; King's Daughters' Hospital, of Shelbyville, Kentucky; and the Clayvillage Baptist Church, of Clayville, Shelby County, Kentucky. (Goldfarb, 2013) [My emphasis]

Goldfarb enquires into the possibility of a punctuation error committed by the attorney: "Was it precise editorial craftsmanship or simple negligence that caused the attorney who drafted this will to join two separate beneficiaries with a conjunction [and], while all the rest were separated by semicolons?" (Ibid.) Whatever the reasons, he concludes that "Either judicial guesswork or imperfect knowledge of the rules of punctuation guided the court in deciding-wrongly-that Jamison and Stivers should each have one-ninth of the bequest, instead of sharing one-eighth" (ibid.).

So far, the cases studied have illustrated the financial issues at stake with regard to the transgression of punctuation norms in legal writing. However, beyond commercial contests, punctuation in legal documents can also be a matter of life and death, as illustrated by the example, cited by Goldfarb, a Washington, D.C. attorney, where the interpretation of the capital punishment statute hinged on the significance of one comma. As Goldfarb (2013) explains: "The defendant in this case had been convicted of murder, second-degree rape, and illegal use of a gun" [my emphasis]. The question concerned the possible sentence, which would depend on the judge's interpretation of the punctuation, the law authorising capital punishment if "the defendant committed the murder while committing or attempting to commit robbery, arson, or rape or sexual offense in the first degree" [my emphasis] (ibid.). 
There was no legislative history to tell the judge whether the Maryland legislature intended to require only the sexual offense or both the sexual offense and the rape to be in the first degree. With no authoritative legislative history to explain the meaning of the law, the judge went to his grammar books and decided that the modifying words in the first degree must be read to apply to both of the offenses following the last comma. The defendant's life was saved by the judge's good grammar. (Ibid.) [My emphasis] claims acceptable "an utterance that complies with the rules of language performance". The notion of acceptability is thought of as relative to the domain of linguistic performance and is opposed to the concept of "grammaticality" and "semanticity", which are relative to the domain of linguistic competence. Grammaticality stands for the conformity to the set of rules intrinsic to the language and with no reference to the outer world of physical reality. The distinction between competence and performance domains, serves as a basis for the development of different levels of acceptability presented by the diagram below:

Figure 1. - Levels of acceptability (Martin, 1978, p. 11).

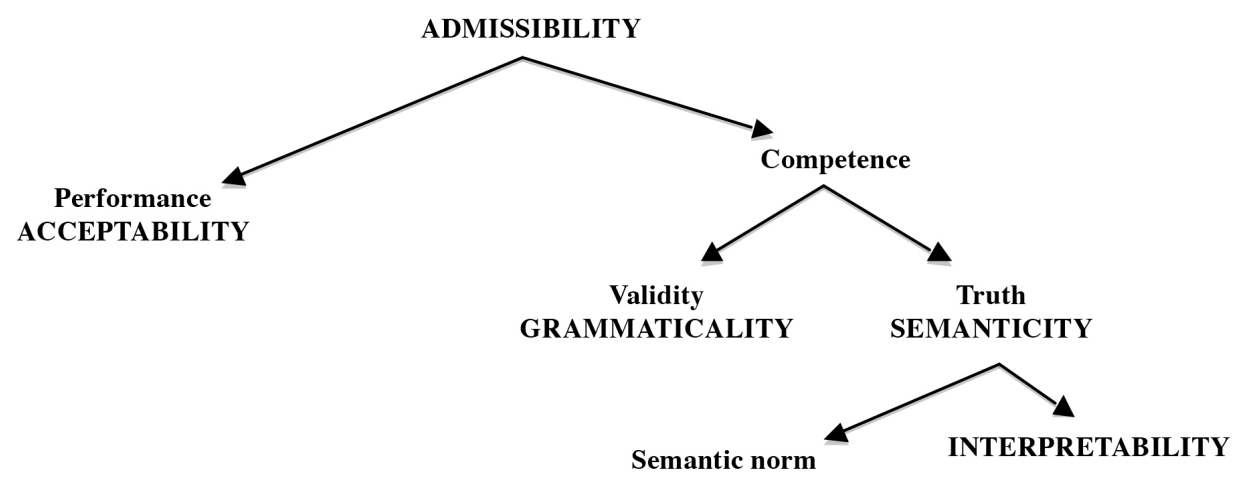

While presenting the bottom level of the admissibility diagram, interpretability is fundamental to the judgements on acceptability. Similarly, in her study on the acceptability of transgressions from grammar norms, Debièvre (1978, p. 128) suggests an interesting classification of deviant utterances based on the criteria of grammaticality 
and interpretability (the capacity of the person receiving the message to perform a semantic analysis of it, i.e. to interpret its meaning). Even though her study is based on the French language, this classification is of interest to us here since it contributes to the study of the criterion of interpretability in acceptability judgements. Three categories of deviant utterances are suggested (ibid.):

a) ungrammatical and uninterpretable;

b) ungrammatical but interpretable;

c) grammatical but uninterpretable.

Most of the utterances examined in her study prove to belong to the second category, i.e. they are interpretable despite being ungrammatical. The theory of language termed 'lexical priming' developed by Hoey (2005) accounts for this phenomenon by putting forward the primacy of lexis over grammar. Hoey advocates in favour of a new theory of lexicon, which reverses the roles of lexis and grammar arguing that "lexis is complexly and systematically structured and that grammar is an outcome of this lexical structure" (Chapter 1, Introduction, § 1). This would account for the fact that certain linguistic structures are interpretable despite being ungrammatical. This brings us to the idea that interpretability may not be an appropriate criterion for judgements on the acceptability of transgressions from grammar norms, for even highly ungrammatical utterances can still be interpretable. Besides, interpretability is a highly relative notion for an utterance that is interpretable for one interlocutor can be uninterpretable for another.

On the other hand, in the framework of ESP teaching, it is of importance to note that as far as the criterion of grammaticality is concerned, it cannot fully meet with the needs and expectations of professional contexts in that it is based on purely linguistic norms. Studying the notion of norms, Debièvre (1978, p. 125) underlines their complex nature by drawing on their twofold character. In broad terms, a norm corresponds to the idea of what is normal, that is, what is observed most frequently and is thereby considered and judged as normal. By contrast, and in more absolute terms, a norm represents a general rule that is established and conceived of as an absolute law beyond judgements. Unlike this latter definition of the norm, in the former broad conception of the term, relative to the idea of what is considered as normal, the judgement as to the compliance of an act with a certain norm is relative and above all socially determined. In this view, a norm can be defined as the standard or the most frequent use prevalent in a social group in a given type of communication. These norms can therefore be referred to as social norms (ibid.).

The importance of social norms in the way language is used in a wide range of corporate contexts to achieve professional goals and establish workplace interaction, has been highlighted by workplace discourse researchers, such as, for example, Marra, who claims that "The nuanced nature of meaning creation relies heavily on the 'here and now', and this situated view of interaction encourages emphasis on local norms and understandings" (2013, p. 181). As far as ESP is concerned, language teaching and learning should take into account these social norms, which could be referred to as 'professional norms' or 'workplace norms'.

Along the same lines, authentic examples from workplace discourse research provide convincing evidence for the importance of compliance with workplace norms over linguistic norms and call for the "emphasis to be placed on practical aspects of English in the form of sociopragmatic competence rather than grammatical accuracy" (Marra, 2013, p. 181). Undeniably, the ultimate goal of ESP courses is to prepare students to meet the needs and expectations of workplace communication. The present study being focused on 
spelling and punctuation, the following quotation from Hyland (2013, p. 95) is of interest to our study as it deals with writing competence in ESP courses:

Unlike older "process" traditions which saw writing as a kind of generic skill which could be taught by modelling expert practices, ESP conceptions of writing focus on assisting students towards competence in particular target genres. Teachers do not simply "teach writing" but teach particular kinds of writing which are valued and expected in some academic and professional contexts. The literacy demands of the modern world, therefore, challenge ESP teachers to recognize that their task involves far more than simply controlling linguistic error or polishing style. Instead it encourages them to respond to a complex diversity of genres, contexts and practices. (Hyland, 2013, p. 95) [My emphasis]

Far from representing the primary and the sole teaching objective, 'controlling linguistic error' is part of ESP teaching goals, which should take into account not only linguistic norms but also socio-professional norms.

\section{Conclusion}

30 In response to the central question of our study "is transgression of language norms acceptable in ESP teaching and learning practices as far as it does not hinder the act of communication?" the following conclusions may be drawn. First, although communication of information is the primary purpose of language acquisition, interpretability of an utterance cannot serve as an objective criterion of acceptability judgement, for, as the study demonstrated, even extremely deviant forms are rarely completely uninterpretable. The adoption of this criterion would therefore lead to the acceptance of almost any deviant form, even those that are highly ungrammatical. Furthermore, given that the assessment of linguistic performance necessarily presupposes a confrontation of two sets of norms, those employed by the speaker/writer and those that are accepted as a model, placing interpretability above language norms would render difficult the process of language assessment vital in ESP teaching practices. Besides, interpretability does not have an absolute character: the same utterance can be more or less interpretable for different interlocutors, or render quite diverse interpretations, thus leaving room for ambiguity or misinterpretation.

31 Second, no unique criterion of acceptability can be determined that would be applicable to all contexts and domains of communication on the one hand, and all language norms, on the other. Each communicative act involves a complex set of dynamics and its outcome depends on the interaction of multiple factors and norms that are at play. This is even more so in contexts of professional communication, where a series of professional considerations, particular to the given specialised domain, play a determinant role. As far as punctuation norms in legal documents are concerned, zero tolerance of their transgression is to be adopted in cases where these norms are determinant for the meaning of the message conveyed and involve crucial stakes. In this case, the transgression of norms would create a source of ambiguity, misunderstanding and conflict. Thus, the acceptability of transgressions of norms is to be judged in reference to a particular language norm in a given act of communication.

Finally, judgements of acceptability need to take into account the context of language usage. While it goes without saying that ESP language acquisition serves language usage in workplace contexts, a clear distinction is to be drawn between the pedagogical context, where the actual teaching and learning process takes place, and workplace contexts, 
where the primary purpose of language usage is to serve professional needs. The former aims at the transmission/acquisition of standard language norms and falls within the domain of language competence, while the latter within that of language performance, the use of language norms for professional purposes. Criteria determining acceptability judgements are to take into consideration the needs and goals particular to the given context of language usage. The goals and needs of the latter cannot determine the acceptability of deviant language forms and thereby the assessment criteria for the former. While in educational contexts, judgement on acceptability serves and leads to assessment of linguistic competence of the ESP learner and largely draws on linguistic norms (grammatical accuracy), in the working world, such judgement goes beyond linguistic competence of the language user and bears on the linguistic performance in a workplace context and is interpreted as relative to professional norms. While the relevance of grammatical accuracy in workplace contexts is measured in relation with different local norms and professional goals, as far as the pedagogical context is concerned, grammatical accuracy remains of great relevance for the assessment of the ESP learner's language competence.

As far as the pedagogical context is concerned, given that language acquisition as a cognitive function consists in the acquisition of language norms in the form of general rules, and the formation of habits of applying these rules, accepting transgressions of language norms in teaching contexts would run contrary to the very nature of the teaching and learning process. By its very definition, the teaching of a language implies the transmission of language norms that constitute the overall language competence, and the learning/acquisition of these norms, respectively. By contrast, in workplace contexts, where language norms are accompanied by some local, socio-professional norms, the transgression of the former norms in favour of the latter may be judged acceptable provided the prevalence of professional communication over grammatical accuracy serves the accomplishment of professional goals.

\section{BIBLIOGRAPHY}

ALGEO John, “America is ruining the English language”, in Laurie Bauer and Peter Trudgill (eds), Language Myths, 1998, pp. 176-82.

BOUTET Josiane, « La part langagière du travail : bilan et évolution », Langage et société, no. 98, 2001, pp. 17-42.

DEACON Terrence, The Symbolic Species: The Co-Evolution of Language and the Human Brain, London, Penguin Books, 1997.

DEBIÈVRE Monique, « La conscience de l'acceptabilité en français contemporain », in Robert Martin (ed.), La notion de recevabilité en linguistique, Paris, Klincksieck, 1978, pp. 125-47.

DEXTER Colin, The Riddle of the Third Mile, London, Pan Books, 1983.

GARRETT Peter, Attitudes to Language, New York, Cambridge University Press, 2010. 
GOODMAN Nelson, Languages of Art: An Approach to a Theory of Symbols, London, Oxford University Press, 1969 [1968].

HOEY Michael, Lexical Priming: A New Theory of Words and Language, New York, Routledge, Kindle edition (Amazon.fr), 2005.

HYLAND Ken, "ESP and Writing”, in Brian Paltridge and Sue Starfield (eds), The Handbook of English for Specific Purposes, first edition, John Wiley \& Sons, Inc., 2013, pp. 95-113.

maturana Humberto \& VAREla Francisco, Autopoiesis and Cognition: The Realization of the Living, Netherlands, Dordrecht, 1980.

MARRA Meredith, "English in the Workplace", in Brian Paltridge and Sue Starfield (eds), The Handbook of English for Specific Purposes, first edition, John Wiley \& Sons, Inc., 2013, pp. 175-92. MARTIN Robert, La notion de recevabilité en linguistique, Paris, Klincksieck, 1978.

MILROY James, “The ideology of standard language”, in Carmen Llamas, Louise Mullany and Peter Stockwell (eds), The Routledge companion to sociolinguistics, London, Routledge, 2007, pp. 133-9. NICKERSON Catherine, "English for Specific Purposes and English as a Lingua Franca", in Brian Paltridge and Sue Starfield (eds), The Handbook of English for Specific Purposes, first edition, John Wiley \& Sons, Inc., 2013, pp. 445-60.

PINKER Steven, Language, Cognition, and Human Nature: Selected Papers, Oxford, Oxford University Press, Kindle edition (Amazon.fr), 2013.

PEIRCE Charles Sanders, Collected Papers of Charles Sanders Peirce, 8 vols; vols 1-6: Ch. Hartshorne and P. Weiss (eds); vols 7 and 8: A. W. Burks (ed.); Cambridge (Mass.), Harvard University Press, 1958 [1931-1936].

TRUSS Lynne, Eats, Shoots \& Leaves: The Zero Tolerance Approach to Punctuation, London, Profile Books, 2003.

VERGELY Pascale, «Le risque du langage en situation de travail », présentation dans Langage et société, no. 125, 2008a.

-, «L'expression du dysfonctionnement technique dans des interactions orales de travail », Langage et société, no. 125, 2008b, pp. 35-54.

\section{Online Resources}

Common European Framework of Reference for Languages: Learning, Teaching, Assessment (CEFR), The Council of Europe, 2011, <www.coe.int/t/dg4/linguistic/Cadre1_en.asp > (consulted 19 September 2013).

GOLDFARB Ronald, “The case of the Kentucky Court of Appeals", 2013 <www.dcbar.org/ for_lawyers/resources/publications/washington_lawyer/march_2004/books.cfm> (consulted 2 December 2013).

HARTLEY Emma \& MILNER Catherine, "Greene family fights for access to papers", The Telegraph, 17 February 2002, <www.telegraph.co.uk/news/uknews/1385107/Greene-family-fights-foraccess-to-papers.html> (consulted 2 December 2013).

LYALL Sarah, "A Literary Battle That May Hang by A Comma”, The New York Times, 16 March 2002, <www.nytimes.com/2002/03/16/books/a-literary-battle-that-may-hang-by-a-comma.html? pagewanted=all\&src=pm> (consulted 2 December 2013). 
The example of the misspelled text appeared on the Internet in September 2003 [online] < www.snopes.com/language/apocryph/cambridge.asp> (12 October 2013).

“The Pluperfect Virus: E-mail Horror", Orlando Sentinel, 5 May 1999, Special to The Washington Post by HIRSCHFELD Bob, <http://articles.orlandosentinel.com/1999-05-05/news/9905040496_1_e-mailattachment-found-that-e-mail-virus> (consulted 3 December 2013).

\section{NOTES}

1. The chief published collection of Peirce's writings is the Collected Papers of Charles Sanders Peirce (CP), and in referring to these volumes, we have adopted the established method of reference used by all Peirce scholars. Thus, CP 5.446 means volume 5, paragraph 446 of the Collected Papers.

\section{ABSTRACTS}

Much ESP teaching is guided, to a great extent, by a general communicative approach. Likewise, the assessment criteria put forward by the CEFR are based on language learners' language multimodality (capacity to use the four skills, reading, writing, listening and speaking) in different socio-professional contexts of communication. The ability to communicate thus acts as a key criterion in assessing language learners' linguistic performance as opposed to grammatical or semantic conformity to norm. This study focuses on written production, and the question of whether transgression from the established language norms (syntax, spelling, etc.) is acceptable as long as it does not hinder the act of communication. To answer this question, some examples of transgressions of language norms regarding two relatively underresearched areas, spelling and punctuation, in professional contexts of communication (legal documents) are studied to measure the impact of transgressions on the performed communicative act.

Dans le domaine de l'enseignement de l'anglais de spécialité, les pratiques pédagogiques sont, en grande partie, guidées par une approche communicative. De même, les critères d'évaluation préconisés par le CECRL se basent sur la multimodalité linguistique des apprenants en langues (la capacité d'utiliser les quatre compétences communicatives - lire, écrire, comprendre et s'exprimer à l'oral) dans différentes situations de communication socio-professionnelles. Ainsi, la capacité de communiquer s'impose comme un critère clé dans l'évaluation de la performance linguistique des étudiants en langues, par opposition à la conformité aux normes grammaticales ou sémantiques. La présente étude s'axe sur la production écrite et constitue une réflexion sur la question suivante : la transgression des normes langagières relatives à la syntaxe, à l'orthographe, etc., est-elle acceptable dans la mesure où elle n'entrave pas l'acte de communication?

Pour tâcher d'apporter des éléments de réponse à cette question, l'étude vise à mettre en lumière l'impact qu'une transgression des normes langagières peut avoir sur l'acte de communication écrite notamment par rapport à deux domaines relativement peu étudiés - l'orthographe et la ponctuation - dans des textes juridiques. 
INDEX

Keywords: ESP teaching, acceptability, transgression, spelling, punctuation, legal writing Mots-clés: enseignement de l'anglais de spécialité, acceptabilité, transgression, orthographe, ponctuation, textes juridiques

\section{AUTHOR}

INESA SAKALIAN-MERLE DES ISLES

University Grenoble Alpes (France), ILCEA 